\title{
SICKNESS ABSENCE IN BUILDING CONSTRUCTION INDUSTRY - A CASE STUDY OF MYSURU CITY
}

\author{
Ananda P \\ Research Scholar, \\ DOS in Social Work, University of Mysore, \\ Mysuru, Karnataka
}

\begin{abstract}
Sickness absence means nonattendance by workers at work due to various reasons when the employer expects attendance. Objectives of the Study: The present study has attempted to discover the causes of the sickness absence among the worker in the building construction industry. Methods and Materials: The cross-sectional study has been conducted. The data collection was done through the Interview schedule. The data collected by the researcher has been computed in factors analysis. Results and Discussion: The first and second components have identified two factors. The other components have identified only one factor. Manual materials handling, psychological fatigue and dissatisfaction with work are identified under component. one. Static work postures are identified under component two. Therefore, Manual materials handling, Lack of Social supports and dissatisfaction with work are the major reasons for the sickness of absence in the building industry. Conclusion: Managing absenteeism can be a helpful measure in understanding the reasons for sickness absence in the workplace. Furthermore, the effective management of leaves reduces sick leave time and puts an end to stress-induced illness. The building construction industry focuses to improve occupational health and employ prevention methods in the working site.
\end{abstract}

Keywords: Sickness Absence, Building Construction Industry, Construction Worker

\section{INTRODUCTION}

Sickness absence means non-attendance by workers at work due to a (certified) health complaint when the employer expects attendance. Despite the unambiguous definition, sickness absence has proved to be a composite phenomenon.

In addition to illness, it has been associated with, for example, demographical and socioeconomic factors, organisational features, job content and

\author{
Dr. Devaraja R, \\ Assistant professor of Social Work, \\ Assistant Government First Grade College, \\ University of Mangalore, Karnataka
}

attitudes to work. (Taimela et al., 2007). Sickness absence, defined as non-attendance by a worker at work due to a health complaint, places a major economic burden on employers, the healthcare system and society as a whole. (Taimela et al., 2007).

The key psychosocial predictors of sickness absence include individuals' perceptions of health and working ability. (Nwaru et al., 2018). The building construction industry is known as one of the most hazardous activities. Therefore, sickness absence is a common factor among building construction workers for various causes. (HASSAN et al., 2007). The building construction workers tend to a range of health disorders that result in absence from work is well documented, and it is recognised that building construction workers are at greater risk of developing certain health disorders than are the general population and workers in other industries. (Brenner, 2000). In sickness absence can be approached through the general possibility of factors causing work disability. The work disability may be perceived as an area that incorporates not only the individual and the disease-causing work disability, but also the work environment, the health care and social security systems, social factors, and the broader societal context. (Leinonen et al., 2018). Sickness related problems there are still gaps in our knowledge of the subject. The observations that work in the building industry have more sickness absence than other industry. (Taylor, 1967). Musculoskeletal injuries mostly related to back pain workplace stress and accounted for all workplace injuries among the top causes of sickness absences in the building industry. (Gabriele Kaier, 2017). The optimal occupational health intervention strategy for workers with a high risk of sickness absence remains uncertain.

\section{REVIEW OF LITERATURE}

(Ferguson, 1972)The study revealed that some characteristics of repeated sickness absence. The study discovered that the frequency of absence attributed to sickness is not distributed randomly 


\section{International Journal of Engineering Applied Sciences and Technology, 2021 \\ Vol. 5, Issue 10, ISSN No. 2455-2143, Pages 214-220 \\ Published Online February 2021 in IJEAST (http://www.ijeast.com)}

but tends to follow the negative binomial distribution, and taken to support the concept of 'proneness' to such absence. The study stated that Individual and group differences in absence attributed to sickness need not be the result of the difference in disease such absence is usually the result of several factors, only one or none of which may be medical. Many non-medicals personal, social, industrial, and organizational factors and considered that almost any personnel practice may influence absenteeism by affecting the desire to work.

(Coenraads \& Nater, 1984) the study discovered that occupational skin disease in building construction and building workers probably are the most important of skin disease cause of sickness and absence of work in the building industry. The study stated that information on the real medical and social importance of these diseases is rare. The study explained that many working days are lost with important financial consequences. The study observed that workers, despite more or less extensive skin disease problems, sometimes try to continue their work without even consulting a physician.

(Arai \& Thoursie, 2004)The study found that workers are a group in an industry facing similar working environments. The study indicated that working conditions, defined as job characteristics, information on the many interesting establishmentlevel characteristics that may influence sickness absence. The study revealed that an important feature of an establishment is, for example, its economic performance and profitability. The study discovered that the industries of work and workplace social norms are likely to be another important decisive factor for both the psychosocial working conditions in the workplace and the sickness absence behaviour are the major reasons for the sickness of absence.

(Brenner, 2000)the study found that disability among building construction workers leading sickness absence to worker leaving the building industry. The study revealed that sickness and absence from work in the construction industry due to skin diseases, occupational dermatoses, and workers sometimes continue to work without consulting a physician.

(Hernando-Rodriguez et al., 2020)The study revealed that increasing life expectancy and job insecurity disturbs the stability in the building industry. The study examined that unstable employment a trodden path might entail the loss of economic resources, a lower likelihood of future employability when unemployed, and most importantly, loss of health. The study found that experiences during working life are usually characterised as changes in employment and working conditions, the changes in employment status that may influence an individual's future health course.

(Ashleigh Webber, 2018) The study found that the Office for National Statistics revealed that the total number of days lost to sickness absence increased by $7 \%$ between 2017 and 2018. Last year 141.4 million sick days were taken compared with 131.5 million in 2017 when they began. The study revealed four most common reasons for sickness absence in 2018 were minor illnesses such as coughs and colds (responsible for $27.2 \%$ of days lost); musculoskeletal problems (19.7\%); "other" reasons including accidents, diabetes, infectious diseases and poisonings (13.7\%) and mental health conditions including stress, anxiety and depression $(12.4 \%)$.

(Jamie Jenkins, 2014) The study found that the most common reason given for sickness absence in 2013 , accounting for $30 \%$, was minor illnesses that cover sicknesses such as cough and colds. The study expressed that kind, of illness incline to have shorter durations and accounted for around 27.4 million days lost, whereas the greatest number of days lost was actually due to musculoskeletal problems in 2013 at 30.6 million days lost. The study also revealed that mental health problems such as stress, depression and anxiety also contributed to a significant number of days of work lost in 2013 at 15.2 million days. The study focused that mental health problems exclude things such as manic depression and schizophrenia which are grouped as serious mental health problems and accounted for just $1 \%$ of the reasons given for sickness.

(Nwaru et al., 2018)The study found that investigates whether sickness absence during participation in a subsidized re-employment program in the building industry influenced the future employability of long-term unemployed people. The Findings suggested that an increased risk of poor labour market attachment among unemployed people with sickness absence, especially among young adults with >30 days of sickness absence. The study concluded that sick unemployed people may require extra support in terms of healthcare and rehabilitation.

\section{STATEMENT OF THE PROBLEM:}

This study is significant to ascertain the cause of the sickness absence among the building 


\section{International Journal of Engineering Applied Sciences and Technology, 2021 \\ Vol. 5, Issue 10, ISSN No. 2455-2143, Pages 214-220 \\ Published Online February 2021 in IJEAST (http://www.ijeast.com)}

construction workers in building construction industries

\section{OBJECTIVES OF THE STUDY:}

1) To ascertain the cause of the sickness absence in the various building construction industries.

2) To discover the major cause of the sickness absence among the building construction workers

\section{SCOPE OF THE STUDY:}

This study aims to ascertain the major sickness reasons in the building construction industries and discover the necessary solutions to tackle the sickness absence among the building workers. The extent of the current study named "Sickness of absence" is limited only to selected building construction industries in Mysuru city.

\section{RESEARCH METHODOLOGY}

\begin{tabular}{|c|c|}
\hline \multicolumn{2}{|c|}{ Research Methodology } \\
\hline Research & Empirical Study \\
\hline Primary data & $\begin{array}{l}\text { Interview method, direct } \\
\text { observation and also by a structured } \\
\text { questionnaire }\end{array}$ \\
\hline $\begin{array}{l}\text { Secondary } \\
\text { data }\end{array}$ & E-journals, E Thesis and websites \\
\hline $\begin{array}{l}\text { Sampling } \\
\text { Methods }\end{array}$ & Stratified Radom Sampling methods \\
\hline Sample area & 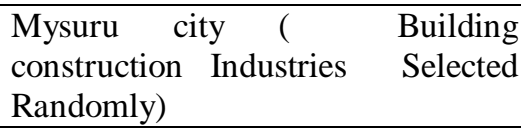 \\
\hline $\begin{array}{l}\text { Study } \\
\text { Population }\end{array}$ & $\begin{array}{l}96 \text { building Construction Industries } \\
\text { Selected for the Study }\end{array}$ \\
\hline Analysis & $\begin{array}{l}\text { SPSS package, Factor Analysis } \\
\text { employed }\end{array}$ \\
\hline Respondents & $\begin{array}{l}\text { Building construction workers Male } \\
\text { and female }\end{array}$ \\
\hline $\begin{array}{l}\text { Valid } \\
\text { sampling } \\
\text { Size } \\
\end{array}$ & $\begin{array}{l}360 \text { worker from Building } \\
\text { Construction Industries }\end{array}$ \\
\hline $\begin{array}{l}\text { Scaling } \\
\text { technique }\end{array}$ & 5 point Scale \\
\hline $\begin{array}{l}\text { structured } \\
\text { questionnair } \\
\text { e } \\
\text { Design }\end{array}$ & $\begin{array}{l}\text { 1th - } 6 \text { the questions contain the } \\
\text { Demographic Profile of workers. } \\
\text { The remaining } 15 \text { questions contain } \\
\text { the opinion of respondents related } \\
\text { to welfare furnished in the building } \\
\text { construction workers }\end{array}$ \\
\hline
\end{tabular}

\section{DATA ANALYSIS AND INTERPRETATION}

\section{Sickness Absence:}

The Labour and workers being engaged in the building industry have been expressing the threat of sickness absence due to health. In the present analysis, an attempt made to identify major sickness absence being associated with the building industry.

The Major Sickness Absence Considered for The Present Study is:

- Manual Materials Handling

- Awkward Back Postures

- Static Work Postures

- Whole-Body Vibration and Hand-Arm Vibration

- Work Characters

- $\quad$ lifting and Motionless Muscular Loading

- $\quad$ Lack of Support at Work

The principal component analysis is a data reduction techniques that give a combination of factors that are jointly contributing to absence due to sickness of labour and workers. The following descriptive statics explain the score for each absence due to sickness in the building industry.

Table: 1

Sickness of Absence

\begin{tabular}{|l|l|l|l|}
\hline Factors & Mean & $\begin{array}{l}\text { Std. } \\
\text { Deviation }\end{array}$ & $\begin{array}{l}\text { Analysis } \\
\mathrm{N}\end{array}$ \\
\hline $\begin{array}{l}\text { Manual Materials } \\
\text { Handling }\end{array}$ & 4.19 & .868 & 360 \\
\hline $\begin{array}{l}\text { Awkward Back } \\
\text { Postures }\end{array}$ & 3.85 & .729 & 360 \\
\hline Static Work Postures & 4.06 & .831 & 360 \\
\hline $\begin{array}{l}\text { Whole-Body } \\
\text { Vibration and Hand- } \\
\text { Arm Vibration. }\end{array}$ & 4.53 & .914 & 360 \\
\hline Work Characters & 4.27 & 1.052 & 360 \\
\hline $\begin{array}{l}\text { lifting and Motionless } \\
\text { Muscular Loading }\end{array}$ & 4.64 & .900 & 360 \\
\hline $\begin{array}{l}\text { Lack of Support at } \\
\text { Work }\end{array}$ & 4.46 & .84684 & 360 \\
\hline $\begin{array}{l}\text { Dissatisfaction with } \\
\text { Work }\end{array}$ & 4.21 & 1.010 & 360 \\
\hline Lack of Control & 4.52 & .984 & 360 \\
\hline
\end{tabular}

Source: Results are computed by using primary data.

The scope for factors of Sickness absence is presented in the above table. It has been found from the table that the highest score is found for lifting and motionless muscular loading and the 


\section{International Journal of Engineering Applied Sciences and Technology, 2021 \\ Vol. 5, Issue 10, ISSN No. 2455-2143, Pages 214-220 \\ Published Online February 2021 in IJEAST (http://www.ijeast.com)}

lowest score was found for awkward back postures. The standard deviation explains the inconsistency in the average score.

From the correlation matrix, it is found that the diagonal matrix is a unit matrix and gives a solution for factor analysis. The highest correlation coefficient value is found between manual material handling and work dissatisfaction, and the highest correlation coefficient value is also found between manual material handling and awkward back postures. It is also proven with many other factors that the correlation coefficient between the factors is other than zero. Therefore, factor analysis is advisable for the present concept of the sickness of absence.

Table:2

Sickness of Absence

\begin{tabular}{|l|lr|l|}
\hline $\begin{array}{l}\text { Kaiser-Meyer-Olkin } \\
\text { Sampling Adequacy. }\end{array}$ & Measure of & .399 \\
\hline \multirow{3}{*}{$\begin{array}{l}\text { Bartlett's Test of } \\
\text { Sphericity }\end{array}$} & $\begin{array}{l}\text { Approx. Chi- } \\
\text { Square }\end{array}$ & 1256.669 \\
\cline { 2 - 4 } & df & 105 \\
\cline { 2 - 4 } & Sig. & .000 \\
\hline
\end{tabular}

Source: Results are computed by using primary data.

The Kaiser-Meyer-Olkin and Bartlett's tests were conducted to identify the adequacy of the sample for factor analysis of the absence of sickness. The KMO value is 0.399 and it greater than.0.5. Hence, samples are adequate for factor analysis. The Chisquare test value is 1256.669 and it is significant at one per cent level. Therefore, there are strong relations among the factor.

Table: 3

Commonalities for Sickness of Absence

\begin{tabular}{|l|l|l|}
\hline Factors & Initial & Extraction \\
\hline Manual Materials Handling & 1.000 & .676 \\
\hline Awkward Back Postures & 1.000 & .836 \\
\hline Static Work Postures, & 1.000 & .730 \\
\hline $\begin{array}{l}\text { Whole-Body Vibration and } \\
\text { Hand-Arm Vibration. }\end{array}$ & 1.000 & .432 \\
\hline Work Characters and Motionless & 1.000 & .722 \\
\hline $\begin{array}{l}\text { lifting } \\
\text { Muscular Loading }\end{array}$ & 1.000 & .585 \\
\hline Lack of Support at Work & 1.000 & .854 \\
\hline Dissatisfaction with Work & 1.000 & .834 \\
\hline Lack of Control Mrincipal & Component \\
\hline $\begin{array}{l}\text { Extraction Method: Prisis. } \\
\text { Analysis. }\end{array}$ & 1.000 & .542 \\
\hline
\end{tabular}

Source: Results are computed by using primary data.

The communalities for factors of the absence of sickness has calculated and found that initial value the factors are one and extraction factors are other than zero. It indicates that each factor individually and jointly impart in determining the absence of sickness. Accordingly, the present factor analysis of the absence of sickness will identify at least one component which represents more than one factor.

Table: 4

Total Variance Explained for Factors Sickness of Absence

\begin{tabular}{|l|l|l|l|}
\hline \multirow{2}{*}{$\begin{array}{l}\text { Compone } \\
\text { nts }\end{array}$} & \multicolumn{3}{|l|}{ Extraction Sum of Squared Lodgings } \\
\cline { 2 - 4 } & Total & $\begin{array}{l}\text { \% } \\
\text { Variance }\end{array}$ & Cumulative \% \\
\hline 1 & 2.148 & 23.872 & 23.872 \\
\hline 2 & 1.674 & 18.604 & 42.476 \\
\hline 3 & 1.269 & 14.098 & 56.574 \\
\hline 4 & 1.119 & 12.434 & $\mathbf{6 9 . 0 0 8}$ \\
\hline 5 & .919 & 10.208 & 79.216 \\
\hline 6 & .738 & 8.195 & 87.411 \\
\hline 7 & .541 & 6.016 & 93.427 \\
\hline 8 & .367 & 4.079 & 97.506 \\
\hline 9 & .224 & 2.494 & 100.000 \\
\hline & & & \\
\hline
\end{tabular}

Extraction Method: Principal Component Analysis

Source: Results are computed by using primary data.

The Total Eigenvalue for the factors of the absence of sickness and the percentage of variance explained by each component has been estimated and presented in the above table. Based on the Eigenvalue; four components are extracted for the absence of sickness. The first components explain 23.872 per cent of the variation in total variation explained by all the variables. The second components explain 18.604 percent of variations. The third component explains 14.098 percent of variations. The fourth component explains 12.434 percent of the variation. To gather four components have explained 69.008 per cent of variations.

The following scree plot also presents the identification of components of factors of an absence of sickness for which, Eigen value is greater than one.

Graph 4.2: Scree Plot for Components of Factors of Absence of Sickness 


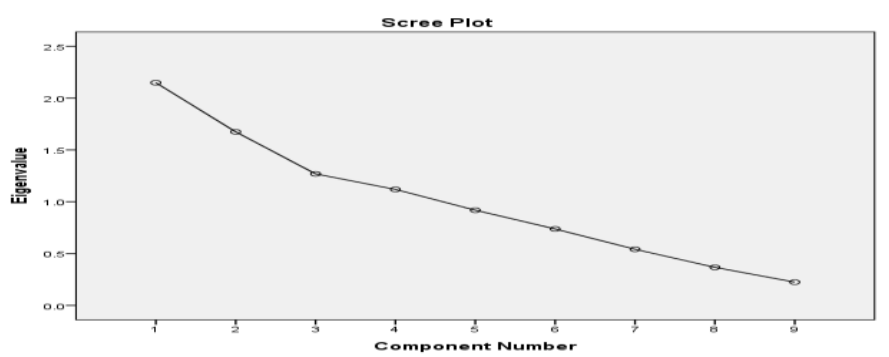

Identification of Factors in Components of Sickness of Absence

Using varimax rotated components matrix for illness has identified the specific factors under each component for which values are greater than 0.7 (A factor loading approximately 0.7 is considered to be sufficient).

Table: 5

Varimax Rotated Component Matrix for Sickness of Absence

\begin{tabular}{|c|c|c|c|c|}
\hline \multirow{2}{*}{ Factors } & \multicolumn{4}{|c|}{ Component } \\
\hline & 1 & 2 & 3 & 4 \\
\hline Manual Materials Handling & .795 & .030 & $\begin{array}{l}- \\
.060\end{array}$ & .435 \\
\hline Awkward Back Postures & $\begin{array}{l}- \\
.064\end{array}$ & $\begin{array}{l}- \\
.029\end{array}$ & $\begin{array}{l}- \\
.028\end{array}$ & .911 \\
\hline Static Work Postures, & $\begin{array}{l}- \\
.145\end{array}$ & .809 & $\begin{array}{l}- \\
.047\end{array}$ & $\begin{array}{l}- \\
.227\end{array}$ \\
\hline $\begin{array}{l}\text { Whole-Body Vibration and } \\
\text { Hand-Arm Vibration. }\end{array}$ & .154 & .313 & .515 & .211 \\
\hline Work Characters & .089 & .805 & .182 & .184 \\
\hline $\begin{array}{l}\text { lifting and } \text { Motionless } \\
\text { Muscular Loading }\end{array}$ &.- & .163 & .716 & $\begin{array}{l}- \\
.057\end{array}$ \\
\hline Lack of Support at Work & .855 & -.197 & .179 & $\begin{array}{l}- \\
.230\end{array}$ \\
\hline Dissatisfaction with Work & .899 & .097 & $\begin{array}{l}- \\
.125\end{array}$ & $\begin{array}{l}- \\
.041\end{array}$ \\
\hline
\end{tabular}

\begin{tabular}{|c|c|c|c|c|}
\hline Lack of Control & .059 & $\begin{array}{l}- \\
.137\end{array}$ & .716 & $\begin{array}{l}- \\
.088\end{array}$ \\
\hline \multicolumn{5}{|c|}{$\begin{array}{l}\text { Extraction Method: Principal Component Analysis. } \\
\text { Rotation Method: Varimax with Kaiser Normalization. }\end{array}$} \\
\hline
\end{tabular}
Source:
using primary data.

The principal component analysis (PCA) for factors of the absence of sickness has performed and found that factors have shown their intuition for more than one component. Hence, the varimax rotation method has been performed and identified the specific factors for each component.

The PCA has identified the factors for all four components. At the same time, it is also confirmed that there is no overlapping of factors and components. The first and second components have identified two factors. The other components have identified only one factor. Manual materials handling, psychological fatigue and dissatisfaction with work are identified under component one. Static work postures are identified under component two. Therefore, Manual materials handling, Lack of Social supports and Dissatisfaction with work are the major reasons for the sickness of absence in the building industry.

\section{RESULTS AND FINDINGS}

- It has been found that the highest score is found for lifting and motionless muscular loading and the lowest score was found for awkward back postures. The standard deviation explains the inconsistency in the average score.

- The highest correlation coefficient value is found between manual material handling and work dissatisfaction, and the highest correlation coefficient value is also found between manual material handling and awkward back postures.

- It has been found that based on the Eigenvalue; four components are extracted for the absence of sickness. The first components explain 23.872 per cent of the variation in total variation explained by all the variables.

- The second components explain 18.604 percent of variations. The third component explains 14.098 percent of variations. The fourth component explains 12.434 percent of 


\section{International Journal of Engineering Applied Sciences and Technology, 2021 \\ Vol. 5, Issue 10, ISSN No. 2455-2143, Pages 214-220 \\ Published Online February 2021 in IJEAST (http://www.ijeast.com)}

the variation. To gather four components have explained 69.008 percent of variations.

- The first and second components have identified two factors. The other components have identified only one factor. Manual materials handling, psychological fatigue and dissatisfaction with work are identified under component one. Static work postures are identified under component two. Therefore, Manual materials handling, Lack of Social supports and Dissatisfaction with work are the major reasons for the sickness of absence in the building industry.

\section{SUGGESTIONS}

- The building construction industries should ensure that the Personnel Protective Equipment is provided in the working place to reduce hazards that leads to sickness absence.

- The building construction industries should implement some employee's wellness programme including a recreational programme to reduce the work dissatisfied among the worker.

- The builder requires emphasizing social supports from the supervisor, safety officers, and other professionals to decrease the sickness absence.

- The building construction industry is labour intensive, hence the adoption of modern innovate technology is required to reduce the possible sickness absence among the worker.

\section{CONCLUSION}

The building construction industries are recognized most pressure industry to accomplish the work in the schedule. The building construction workers often similarly tend to sickness absence most of the reasons. There are various factors linked to including manual materials handling, awkward back postures, lack of support at work and dissatisfaction with work. Therefore, the employer required to adopt more intervention programme to reduce sickness absence. The employer must provide the Personnel protective equipment's to the building worker to reduce the workload and sickness absence.

\section{REFERENCES}

1 Arai, M., \& Thoursie, P. (2004). Sickness absence: Worker and establishment effects. Swedish Economic Policy Review, 11, 9-28.

2 Ashleigh Webber. (2018). Sickness absence increases to 4.4 days per worker-Personnel
Today [Personnel today]. Occupational Health and Welbieng. https://www.personneltoday.com/hr/sicknessabsence-2018-increase/

3 Brenner, H. (2000). Sickness absence and early retirement on health grounds in the construction industry in Ireland. Occupational and Environmental Medicine, 57(9), 615-620. https://doi.org/10.1136/oem.57.9.615

4 Coenraads, P. J., \& Nater, J. P. (1984). Sickness and absence from work due to skin diseases in the construction industry. Review of the literature. Dermatosen in Beruf Und Umwelt. Occupation and Environment, 32(1), 17-21.

5 Ferguson, D. (1972). Some characteristics of repeated sickness absence. Occupational and Environmental Medicine, 29(4), 420-431. https://doi.org/10.1136/oem.29.4.420

6 Gabriele Kaier,. (2017). How to reduce sickness absence in your business. How to Reduce Sickness Absence in Your Business. https://www.timetac.com/en/blog/reducesickness-absence-business/

7 HASSAN, C. R. C., BASHA, O. J., \& HANAFI, W. H. W. (2007). Perception of building construction workers towards safety, health and environment. 2, 10.

8 Hernando-Rodriguez, J. C., Serra, L., Benavides, F. G., \& Ubalde-Lopez, M. (2020). Sickness absence trajectories following labour market participation patterns: A cohort study in Catalonia (Spain), 2012-2014. BMC Public Health, 20(1), 1306. https://doi.org/10.1186/s12889-020-09396-9

9 Jamie Jenkins. (2014). Sickness absence in the labour market. National Stastics in UK, 4(1), 21.

10 Leinonen, T., Viikari-Juntura, E., HusgafvelPursiainen, K., Virta, L. J., Laaksonen, M., Autti-Rämö, I., \& Solovieva, S. (2018). Labour Market Segregation and Gender Differences in Sickness Absence: Trends in 2005-2013 in Finland. Annals of Work Exposures and Health, 62(4), 438-449. https://doi.org/10.1093/annweh/wxx107

11 Nwaru, C. A., Kivimäki, M., Pentti, J., Vahtera, J., \& Virtanen, P. (2018). Sickness absence in a re-employment program as a predictor of labor market attachment among long-term unemployed individuals: A 6-year cohort study in Finland. Scandinavian Journal of Work, Environment \& Health, 44(5), 496502. https://doi.org/10.5271/sjweh.3742

12 Taimela, S., Laara, E., Malmivaara, A., Tiekso, J., Sintonen, H., Justen, S., \& Aro, T. (2007). Self-reported health problems and sickness absence in different age groups predominantly engaged in physical work. 
International Journal of Engineering Applied Sciences and Technology, 2021 Vol. 5, Issue 10, ISSN No. 2455-2143, Pages 214-220

Published Online February 2021 in IJEAST (http://www.ijeast.com)

Occupational and Environmental Medicine, 64(11), 739-746.

https://doi.org/10.1136/oem.2006.027789

13 Taylor, P. J. (1967). Individual Variations in Sickness Absence. Occupational and Environmental Medicine, 24(3), 169-177. https://doi.org/10.1136/oem.24.3.169 